\title{
Doing Content and Language Integrated Learning With a Minority Language: A Teacher Development Model
}

\author{
Marcella Menegale (Corresponding author) \\ Department of Linguistics and Comparative Cultural Studies \\ Ca' Foscari University of Venice \\ Dorsoduro 1075, 30123 Venezia, Italy \\ E-mail: menegale@unive.it
}

Ada Bier

Department of Linguistics and Comparative Cultural Studies

Ca' Foscari University of Venice

Dorsoduro 1075, 30123 Venezia, Italy

Received: April 27, 2020

Accepted: May 11, 2020

Published: May 18, 2020

doi:10.5296/ijl.v12i3.16921

URL: https://doi.org/10.5296/ijl.v12i3.16921

The Authors would like to acknowledge funding by the Dep.t of Linguistics and Comparative Cultural Studies of Ca' Foscari University of Venice within the Eduka2 Project (Interreg V-A Italia-Slovenia 2014-2020 programme, European Regional Development Fund)

Although both Authors have equally contributed to the conception and planning of the present contribution, paragraphs 1, 4.3, 4.4, 5 and 7 should be attributed to Ada Bier, and paragraphs 2, 3, 4.1, 4.2, and 6 should be attributed to Marcella Menegale. The remaining parts should be attributed to both Authors.

\begin{abstract}
Recent research suggests that minority languages cannot be lastingly revitalised unless related functional literacy skills become an explicit educational goal. Focussing on the Friulian minority language in Italy, this paper discusses the importance of developing literacy skills in the minority language. In line with this, a new teacher development model in CLIL has been conceived and piloted with a small group of teachers of Friulian. The findings of the study suggest that the model was effective in relation to both the development of teaching
\end{abstract}


skills in CLIL and in literacy related issues and, more in general, to the promotion of teacher autonomy.

Keywords: CLIL (Content and Language Integrated Learning), Minority language, Literacy, Professional development, Teacher training

\section{Introduction}

Coherently with the efforts invested in the fostering of multilingualism, the European Union has made a clear commitment to protecting and promoting minority languages present in Member States (Note 1). In particular, official policy documents highlight the pivotal role of education in maintaining the status and furthering the development of minority languages. Nevertheless, 'maintenance' may not be sufficient for some of them, for example the unique ones, that is those which do not have a majority status anywhere except where they are spoken (van Dongera et al., 2017, p. 10-11). This is the case of Friulian.

The Friulian language belongs to the family of Rhaeto-Romance languages. Although it is spoken by around 600,000 people (ARLeF, 2015) in the Friuli Venezia Giulia Region, North-Eastern Italy, Friulian has been ranked as a "definitely endangered" language by UNESCO, due to the fact that it is no longer learnt as a mother tongue by children at home (Moseley, 2010). When it obtained official recognition of its status as a minority language (Law 482/1999) (Note 2), several projects started, which aimed at promoting and enhancing its use at school, alongside the Italian (national, majority) language and the foreign languages included in the curriculum (English and others). However, despite the efforts made by the regional administration, language revitalisation has always struggled to invest Friulian with proper dignity in education, so that the promotion of the language at school is not as effective as it could be, especially in a long-term perspective.

Petris (2014) provides quite a comprehensive picture of the state of the Friulian language in education at different school levels, highlighting some paradoxes:

1) Although Law $482 / 1999$ states that minority language education must be guaranteed, in reality it is subjected to availability of State and regional funding, and teachers' willingness to take responsibility for dedicated projects;

2) While the Region has issued guidelines on how to introduce the teaching of and through Friulian in compulsory education (Regional Law 29/2007 (Note 3)), in reality the possibility to learn Friulian at school has been conceived as a curricular option left to parents' approval (cf. Cisilino 2014): this circumstance has generated a critical situation, since many families do not perceive Friulian as a necessary competence to be acquired at school and, as a consequence, the presence of Friulian is neither systematic nor continuous throughout the different school levels;

3) Although the Region has developed specific directives in order to help teachers plan Friulian language education according to school level, only kindergarten and primary school teachers can count on the availability of published teaching materials, whereas 
both lower and upper secondary-school teachers have to create their own materials if they wish to teach Friulian or through Friulian.

\section{The Role of Blended Training in CLIL Teacher Training in Italy}

Although research on teacher professional development in CLIL appears to be a less-researched area in Italy (Coonan, 2011; De Santo \& De Meo, 2016; Di Martino \& Di Sabato, 2012), over the last twenty years, many different kinds of university-run professional development programmes in CLIL have been offered to in-service Italian teachers. In the last years, the general trend towards blended courses - that is, courses where part of the traditional face-to-face instruction is replaced by web-based online learning - is witnessed in the CLIL training context as well: not only does this have to do with feasibility, as online sessions allow for better time investment and management, but also with the fact that teachers can be introduced to affordable and useful technologies. Underpinned by social constructivism (Vygotsky, 1962) and social interdependence (Johnson \& Johnson, 1989), blended training requires teachers to perceive themselves as a community that encourages and values each other's efforts to increase their professional knowledge and skills; they may construct meaning and consolidate understanding through reflective discussion, both written (in forum posts during online sessions) and spoken (in spontaneous verbal dialogue during face-to-face meetings).

In the context of teacher training in CLIL with Friulian, a blended approach may allow minority language teachers to develop three types of skills: teaching, social, and learning-how-to-learn skills. Teaching skills are enhanced through both the acquisition of knowledge about the CLIL approach and related methodologies, and the understanding of the value of technology as a medium of learning; actual development arises from the practical application of such knowledge, which is employed to carry out cooperative online activities and the design of CLIL materials for the minority language, where ICT-based learning tasks are embedded. Social skills are encouraged by involving participants in a community of CLIL minority language teachers who share their ideas, knowledge, similar worries, resources, and goals. Learning-how-to-learn skills are promoted by raising teachers' awareness of the need to change their established pedagogical habits so as to effectively teach in a CLIL context and to take on those qualities that a CLIL minority language teacher needs to have, namely, professional values, professional development, language knowledge, subject knowledge, pedagogical knowledge, understanding of learners and their (language) learning, readiness to experiment new practices (Papaja, 2013, p. 147), also through action-research according to the principles of "reflective practice" (Hopkins, 1985).

Several training projects of this kind targeting teachers of different school levels have been implemented so far, thanks to both national and regional funding (cf., for example, Perini, 2010; Perini \& Senesi, 2012). However, although these projects helped strengthen the value of Friulian in education, increasing its presence throughout the school curriculum, the use of Friulian in schools has remained confined to oral tasks. In fact, the shortage of educational materials in the different school subjects and at different cognitive and language levels, 
restricts the possibility of developing pupils' reading and writing skills, resulting therefore in limited literacy skills in Friulian.

\section{Literacy Skills in the Minority Language}

Research has shown (cf. Eisenchlas et al., 2013) the positive outcomes to be got from being literate in a minority language, especially when it is the pupils' home language. Literacy is defined as the "ability to read and write at a level whereby individuals can effectively understand and use written communication in all media (print or electronic), including digital literacy" (Valtin et al., 2016, p. 3). It appears that literacy is a multi-level ability, as the European Literacy Policy Network (ELINET) (Note 4) points out:

1) Baseline literacy means having the knowledge of letters, words and text structures that is needed to read and write at a level that enables self-confidence and motivation for further development.

2) Functional literacy stands for the ability to read and write at a level that enables someone to develop and function in society, at home, at school and at work.

3) Multiple literacy corresponds to the ability to use reading and writing skills in order to produce, understand, interpret and critically evaluate written information. It is a basis for digital participation and making informed choices pertaining to finances, health, etc.

Whether it is acquired simultaneously with literacy development in the majority language or not, baseline literacy skills in the minority language bring cognitive and academic advantages like, for example, long-lasting lexical expansion, fluency, appropriate use of grammar structures, meta-linguistic and phonological awareness, ability to decode and interpret text, working memory, and enhanced attention (cf. Bialystok, 2001; Eisenchlas et al., 2013). In parallel, the development of functional literacy, which contributes to enabling individuals to learn the appropriate use of registers and style (Baker, 2011), is important for mastering the skills needed to act in everyday social and professional life. Finally, as literacy is now considered not only as standard writing and speaking but also as multiple, multi-modal and multi-mediated, we speak of 'multiliteracies' (Cope \& Kalantzis, 2015), a term which includes non-linguistic representations and ways of communicating by means of technology.

In order to promote these three levels of literacy, curriculum development requires attention, so that it can be integrated with materials, resources and tasks that can develop these literacy skills; this may translate into working on a variety of texts pertaining to different domains, so that pupils acquire competence and confidence in specific registers and vocabulary use in the minority language. Evidently, the shortage of multimodal graded learning materials for minority language learners represents a major challenge for teachers. More investment is needed to provide both teachers and students of different levels of instruction with appropriate multimodal content area materials in minority languages which should be as "plentiful, professionally produced and high-quality" (Malone, 2004, p. 6), also using technology - as is done for the majority languages. 
Along with literacy development-oriented resources, attention is to be paid to curriculum aims. Minority languages are better promoted when "strong" forms of bilingual education are put in place, that is, when bilingualism and biliteracy "at no cost to general academic achievement" are pursued (Baker, 2007, p. 142). As was found in Mezgec's (2011) study with Slovene minority language students in Friuli Venezia Giulia, having a minority language as both home language and medium of instruction at school does not seem to be sufficient for developing functional literacy skills, unless these are explicitly set and pursued as learning goals.

Such being the case, investing in specific approaches which integrate the Friulian language into the curriculum and conceive the development of literacies in the minority language as a learning milestone may lead to the real promotion of the language, not just to its mere maintenance. While waiting for the education system to take a stronger position on all this, the challenge is first of all in the teachers' hands, in their willingness to constantly renew their teaching methods according to the most recent and scientifically informed approaches, like Content and Language Integrated Learning, CLIL (Perini, 2006).

\section{The Study}

Starting from the premises discussed so far, we aimed at devising and validating a model of teacher development in CLIL for minority language teachers by means of a training programme which could:

a) develop awareness among teachers about literacy issues and ways to strengthen pupils' literacy skills in the Friulian language;

b) treat the minority language as a target language also with a view to sustaining the development of the teachers' meta-competence and raise their awareness about the language itself;

c) promote skills in the use of technologies for education to help teachers find adaptable classroom resources and to create their own materials for the minority language;

d) adopt a learning-by-doing approach where the teachers are engaged in practical tasks on the language minority issues, the results of which can be readily applied in their classrooms;

e) foster their teacher autonomy through both their individual professional development and the creation of a community of practice (Lave \& Wenger, 1991) sharing a common goal, namely, to improve their teaching practice in order to pursue the development of pupils' literacy skills in the Friulian language and, more broadly, to promote the minority language in the long term;

f) be reasonably feasible for Friulian teachers to attend, given that they often come from out-of-the-way geographical areas and reaching the main town centres where classes normally take place often calls for lengthy journeys. 


\subsection{The Components of the Model}

The teacher development model includes three main components, as Figure 1 shows:

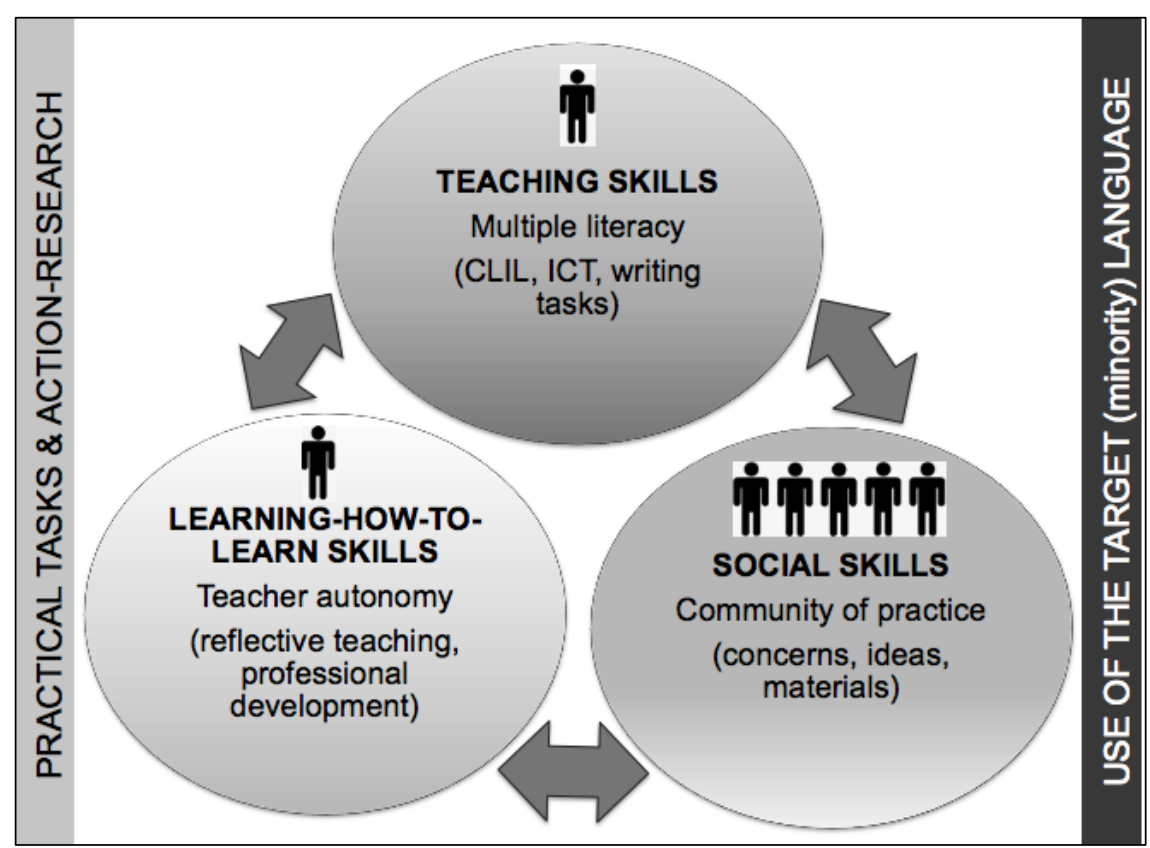

Figure 1. A model of teacher development in CLIL for minority language teachers

1) coaching on specific teaching skills.

This component covers the 'contents' of the training programme which are designed to provide teachers with in-depth understanding of the theories and principles underpinning the CLIL approach and the methodological skills needed to be able to adopt a multiple-literacy pedagogy in and thorough a minority language. Through a learning-how-to-learn process and by means of an action-research practice, they are asked to accomplish a series of practical tasks in order to develop these skills. First, they are trained in finding, planning and designing CLIL teaching materials (e.g. module plans, lesson plans, worksheets, etc.) for the minority language, in adopting scaffolding techniques for text comprehension and production, in preparing task-based classroom activities requiring pair/group work and critical thinking on the part of the pupils, and in giving appropriate feedback and evaluation, thus supporting both content and language learning. Second, since the development of the pupils' multiple literacy skills in Friulian is a central issue, teachers are called on to design reading and writing tasks aimed at developing academic language in the minority language. Finally, special attention is also given to the use of Information and Communication Technologies (ICTs) for education, which are carefully integrated into the training programme both in the form of study material (e.g. video-lessons, tutorials, web resources) and as authentic tasks to be completed (e.g. teachers are asked to create a Digital Storytelling, to produce their own video-lessons, to record a podcast);

2) exercising key social skills.

This component regards the 'learning process' encouraged during the training programme with the aim of creating a community of practice. Teachers support each other in a 
co-constructive learning environment. Teachers are constantly encouraged to exchange experiences, doubts, limits, ideas, facts, and knowledge. Whenever possible, the language used for interaction is Friulian, so that the teachers' competence and awareness about the target language can be mutually enhanced. Moreover, the teachers also work together in the preparation of the teaching materials which are subject to feedback via group discussion and which are shared at the end of the course by using the learning platform as a repository;

3) promoting learning-how-to-learn skills.

This component encompasses those actions aimed at engaging teachers in 'meta-level' thinking. The purpose here is to foster those attitudes and skills needed to boost teacher autonomy. Teachers are guided to reflect on their own motivation, professional competence, personal beliefs and teaching actions by means of a series of tools and processes adopted throughout the training programme (cf. Richards \& Lockhart, 1996, on "reflective teaching") like a teacher diary, to keep logs while experimenting CLIL lessons, and reflective comments to prompt online or focus-group discussion (possible themes are: the importance of written language to develop students' literacy skills in Friulian, the need to adopt the standardised spelling system which may differ from local varieties, the difficulty of promoting Friulian in areas where it is not widely spoken, the need to address new teaching, curricular, or personal challenges in their professional development experiences). Assessment may be devised as a reflective process so as to encourage teachers' involvement in their professional development, by means of different forms of formative assessment (i.e. individual feedback as well as peer-to-peer, collective and self-assessment).

Borders between the three components are not clear-cut, there is a degree of overlapping between them, and the main reason for this is that they are closely interconnected, as each affects - and is affected in turn - by the others.

\subsection{Research Questions}

In order to understand whether the model was effective in promoting professional development in CLIL for minority language teachers, the following research questions were formulated:

RQ1. To what extent were teaching skills promoted, in relation to CLIL, ICT and literacies in the minority language?

RQ2. How did participants perceive the exercise of key social skills aimed at creating a community of practice for the minority language teachers?

RQ3. To what extent were learning-how-to-learn skills and teacher autonomy oriented to CLIL with a minority language fostered through the pilot programme? 


\subsection{Participants}

Table 1. School level, number of teachers, titles

\begin{tabular}{|c|c|c|c|}
\hline School Level & $\begin{array}{l}\text { Nr. of } \\
\text { Teachers }\end{array}$ & & Title of CLIL Modules in Friulian \\
\hline $\begin{array}{l}\text { Kindergarten } \\
\text { (last year) }\end{array}$ & 1 & M1 & $\begin{array}{l}\text { Musiche, colôrs, emozions... Relè e l'insium dal } \\
\text { Guggenheim } \\
\text { [trans. Music, colours, emotions... Relè and the } \\
\text { Guggenheim dream] }\end{array}$ \\
\hline Kindergarten-Primary & 2 & M2 & $\begin{array}{l}\text { Flaba par gno fradi piçul } \\
\text { [trans. Story for my younger brother] }\end{array}$ \\
\hline Primary ( $1^{\text {st }}$ year $)$ & 2 & M3 & $\begin{array}{l}\text { L'aur da la fatorie: Lis bestiis! } \\
\text { [trans. The gold in the farm: animals!] }\end{array}$ \\
\hline Primary $\left(1^{\text {st }}, 2^{\text {nd }}\right.$ year $)$ & 2 & M4 & $\begin{array}{l}\text { Tal zardin de scuele o ai scuviert che... } \\
\text { [trans. In the school garden I discovered that...] }\end{array}$ \\
\hline Primary ( $3^{\text {rd }}$ year $)$ & 2 & M5 & $\begin{array}{l}\text { Sore e sot aghe } \\
\text { [trans. Above and under water] }\end{array}$ \\
\hline Primary $\left(2^{\text {nd }}, 4^{\text {th }}\right.$ year $)$ & 1 & M6 & $\begin{array}{l}\text { I cavalîrs a àn il non cun se } \\
\text { [trans. As Gentle as Silkworms] }\end{array}$ \\
\hline Primary ( $2^{\text {nd }}$ year $)$ & 2 & M7 & $\begin{array}{l}\text { "... come i fasui inte cite..." } \\
\text { [trans. Like beans in a pot] }\end{array}$ \\
\hline Primary $\left(1^{\text {st }}, 3^{\text {rd }}\right.$ year $)$ & 2 & M8 & $\begin{array}{l}\text { Il Friûl magjic } \\
\text { [trans. Magic Friuli] }\end{array}$ \\
\hline Primary ( $4^{\text {th }}$ year $)$ & 1 & M9 & $\begin{array}{l}\text { Aghe e aiar } \\
\text { [trans. Water and air] }\end{array}$ \\
\hline Primary ( $4^{\text {th }}$ year $)$ & 2 & M10 & Gjoldi il fûc / Enjoy fire \\
\hline $\begin{array}{l}\text { Low-Secondary } \\
\left(2^{\text {nd }} \text { year }\right)\end{array}$ & 1 & M11 & $\begin{array}{l}\text { Jerbis par preâ, jerbis par curâ. Un ort plen di } \\
\text { segrets } \\
\text { [trans. Herbs to prey, herbs to cure. A garden full } \\
\text { of secrets] }\end{array}$ \\
\hline $\begin{array}{l}\text { Low-Secondary } \\
\left(2^{\text {nd }} \text { year }\right)\end{array}$ & 1 & M12 & $\begin{array}{l}\text { La poesie e il viaç } \\
\text { [trans. Poetry and the journey] }\end{array}$ \\
\hline TOT. & 19 & & 12 \\
\hline
\end{tabular}

A total of 19 in-service teachers took part in the pilot training programme (Table 1). Most participants taught at Primary school level (pupils' age: 6-10), while the others in 
Kindergarten (pupils' age: 3-5) and Lower-Secondary school (pupils' age: 11-13). All of them were competent speakers of Friulian.

\subsection{Methodology}

The study adopted a mixed-methods approach (Dörnyei, 2007), where a main qualitative component is combined with a quantitative one, in which descriptive statistics are employed. A variety of data were collected, both during the training programme (research field notes about online and face-to-face activities, and teachers' diaries) and the end of the course (feedback questionnaire and CLIL teaching materials in Friulian produced by participating teachers). As a means to improving the accuracy of the findings, triangulation of different types of data was envisaged in order to investigate the research topic from different perspectives.

\subsubsection{Data Collection Procedure}

Procedures for collecting the data will be described according to the instruments adopted.

a. Teaching materials

As shown in Table 1, the CLIL teaching materials in Friulian produced by the teachers consist of twelve modules in which a variety of subjects is dealt with (from science to poetry, from folkloric tales to physical education) through the medium of Friulian.

Data were collected according to three main indicators, which correspond to some of the main teaching skills participants were expected to achieve through the training programme:

- teachers' digital literacy: whether teacher-authors adopted any of the educational ICTs which they received training in either for creating the material itself and/or as embedded in the teaching/learning activities proposed;

- promotion of written production in Friulian: whether teacher-authors included tasks for the improvement of the written language; if present, such production activities could be at the word-level (the most basic), sentence-level, or text-level (the most complex);

- promotion of students' meta-competence and self-assessment: whether teacher-authors provided any self-assessment activities for students to help them improve their meta-competence and awareness of language.

b. Teachers' diaries

As teachers' diaries were conceived as a means to allowing insights into the teaching process, participating teachers were recommended to compile their diary on a lesson-by-lesson basis, with a view to obtaining continuous feedback both on how the lessons of their CLIL module were going and on teachers' perceptions of their actions (Note 5). When two teachers collaborated on the same CLIL module, they compiled a single diary together.

The diary consisted of two parts: a six-target self-observation sheet to guide teachers in their reflections and in monitoring their lessons (see Table 2) and two reflective questions, aimed 
at helping teachers ponder over their professional development (What are/could be your future training needs as far as CLIL is concerned? Any reflections, suggestions, ideas?).

c. Feedback questionnaire

The questionnaire, anonymous and paper-based, was composed of 14 items: most of them were open-ended short-paragraph questions, the remaining were dichotomic yes/no items and multiple-choice questions. Only 7 of the 14 questionnaire items, being directly related to the topic of the present paper, are considered here.

The questionnaire was filled out by 17 respondents (out of 19, cf. Table 1).

d. Research field notes

Research field notes helped monitor teachers' participation and behaviour during the course (e.g. forum posts on the online platform, Moodle, use of the target language by participants in both oral and written form, significant anecdotes).

\subsubsection{Data Analysis Procedures}

As for teaching materials, the analysis of the data was descriptive and mainly consisted of a frequency count (cf. Table 3): for each of the three indicators (i.e. teachers' digital literacy, promotion of written production in Friulian, promotion of students' meta-competence and self-assessment), the frequency of CLIL teaching materials displaying the teaching skill in question was computed as a means to understanding whether, on the whole, the teachers-authors had mastered such skills.

As for the teachers' diaries and the six-target self-observation sheet, the most frequent score (i.e. the mode) for each target in each CLIL module was considered (cf. Table 2). Parallelly, for the analysis of answers to the reflective questions, the most recurring themes were identified and considered in connection with the components of the model.

Concerning the analysis of the qualitative data obtained through the feedback questionnaire, these were first transcribed. A Grounded Theory, bottom-up approach was then adopted for the analysis of the open-ended questions, with an initial coding phase in which raw data were coded into separate nodes and a focussed coding phase in which, starting from the most salient nodes, larger amounts of data were organised, integrated and synthesised (Charmaz, 2006, p. 46). Nodes and their frequencies were reported in histograms (cf. paragraph 5).

The research field notes were resorted to during the whole process of analysis, as a means to shedding light on issues emerging from the analysis of data which would otherwise have remained opaque.

\section{Results}

In this section, results will be presented according to the Research Questions posed.

RQ1. To what extent were teaching skills promoted, in relation to CLIL, ICT and literacies in the minority language? 


\section{Ml Macrothink}

International Journal of Linguistics

ISSN 1948-5425

2020, Vol. 12, No. 3

To answer this question, data from the teacher diaries (Table 2) and teaching materials (Table

3) were used.

Table 2. Analysis of teachers' diaries

\begin{tabular}{llllllllll}
\hline $\begin{array}{l}\text { CLIL } \\
\text { Modules }\end{array}$ & \multirow{2}{*}{ Compilation } & $\begin{array}{l}\text { Nr. } \\
\text { Lessons }\end{array}$ & $\begin{array}{l}\text { T1 } \\
\text { (mode) }\end{array}$ & $\begin{array}{l}\text { T2 } \\
\text { (mode) }\end{array}$ & $\begin{array}{l}\text { T3 } \\
\text { (mode) }\end{array}$ & $\begin{array}{l}\text { T4 } \\
\text { (mode) }\end{array}$ & $\begin{array}{l}\text { T5 } \\
\text { (mode) }\end{array}$ & $\begin{array}{l}\text { T6 } \\
\text { (mode) }\end{array}$ \\
\hline M1 & end-of-module & NA & $\mathbf{5}$ & $\mathbf{5}$ & $\mathbf{5}$ & $\mathbf{4}$ & $\mathbf{4}$ & $\mathbf{5}$ \\
\hline M2 & end-of-module & NA & $\mathbf{4}$ & $\mathbf{4}$ & $\mathbf{3}$ & $\mathbf{5}$ & $\mathbf{4}$ & $\mathbf{4}$ \\
\hline M3 & lesson-by-lesson & 7 & $\mathbf{4}$ & $\mathbf{4}$ & $\mathbf{4}$ & $\mathbf{5}$ & $\mathbf{4}$ & $\mathbf{5}$ \\
\hline M4 & lesson-by-lesson & 20 & $\mathbf{4}$ & $\mathbf{4}$ & $\mathbf{5}$ & $\mathbf{5}$ & $\mathbf{4}$ & $\mathbf{5}$ \\
\hline M5 & lesson-by-lesson & 9 & $\mathbf{5}$ & $\mathbf{5}$ & $\mathbf{5}$ & $\mathbf{5}$ & $\mathbf{4}$ & $\mathbf{5}$ \\
\hline M6 & lesson-by-lesson & 4 & $\mathbf{4}$ & $\mathbf{4}$ & $\mathbf{5}$ & $\mathbf{5}$ & $\mathbf{4}$ & $\mathbf{5}$ \\
\hline M7 & lesson-by-lesson & 6 & $\mathbf{5}$ & $\mathbf{5}$ & $\mathbf{5}$ & $\mathbf{5}$ & $\mathbf{4}$ & $\mathbf{5}$ \\
\hline M8 & end-of-module & NA & $\mathbf{4}$ & $\mathbf{4 , 5}$ & $\mathbf{4 , 5}$ & $\mathbf{5}$ & $\mathbf{3 , 4}$ & $\mathbf{4}$ \\
\hline M9 & end-of-module & NA & $\mathbf{4}$ & $\mathbf{4}$ & $\mathbf{4}$ & $\mathbf{4}$ & $/$ & $\mathbf{4}$ \\
\hline M10 & lesson-by-lesson & 4 & $\mathbf{4}$ & $\mathbf{4}$ & $\mathbf{5}$ & $\mathbf{5}$ & $\mathbf{4}$ & $\mathbf{4}$ \\
\hline M11 & lesson-by-lesson & 11 & $\mathbf{4}$ & $\mathbf{3 , 4}$ & $\mathbf{5}$ & $\mathbf{4}$ & $\mathbf{5}$ & $\mathbf{4}, \mathbf{5}$ \\
\hline M12 & lesson-by-lesson & 12 & $\mathbf{5}$ & $\mathbf{5}$ & $\mathbf{5}$ & $\mathbf{5}$ & $\mathbf{5}$ & $\mathbf{4}$ \\
\hline
\end{tabular}

Table 2 shows the analysis of the six-target self-observation sheets in the teachers' diaries. Teachers were asked to assign a score to each target on a Likert scale from 1 (minimum) to 5 (maximum): T1) appropriate content and language objectives, T2) objectives achieved, T3) appropriate strategies and methodology, T4) pupil motivation and progress, T5) balance between content and language, and T6) effectiveness of materials. It was found that the most frequent scores assigned to the six targets are the highest available, 4 and 5, which indicates that teachers perceived that they had mastered the necessary skills for effective CLIL teaching for the minority language. It is noteworthy that T4 (student motivation), T3 (appropriate methodology) and T6 (effective materials) are those which received the highest scores overall.

Table 3. Analysis of teaching materials

\begin{tabular}{|c|c|c|c|c|c|c|}
\hline \multirow[b]{2}{*}{ CLIL Modules } & \multicolumn{2}{|c|}{ Teachers' digital literacy } & \multicolumn{2}{|c|}{$\begin{array}{l}\text { Promotion of written } \\
\text { production in Friulian } \\
\text { (learning by doing) }\end{array}$} & \multicolumn{2}{|c|}{$\begin{array}{l}\text { Promotion of } \\
\text { students' } \\
\text { meta-competence, } \\
\text { self-assessment }\end{array}$} \\
\hline & no & yes & no word & $\begin{array}{l}\text { sen- } \\
\text { tence }\end{array}$ & no & yes \\
\hline M1 & & web-search with IWB & $X$ & & $X$ & \\
\hline M2 & & ppt \& video & $X$ & & & $\mathrm{X}$ \\
\hline M3 & $X$ & & $\mathrm{X}$ & & & $\mathrm{X}$ \\
\hline M4 & & digital storytelling & $X$ & & & $\mathrm{X}$ \\
\hline M5 & $X$ & & $X$ & & & $X$ \\
\hline
\end{tabular}




\begin{tabular}{|c|c|c|c|c|c|c|c|}
\hline M6 & & $\begin{array}{l}\text { tablet, IWB, digital } \\
\text { storytelling }\end{array}$ & & $X$ & & & $\mathrm{X}$ \\
\hline M7 & & $\begin{array}{l}\text { kahoot, comic-strip, } \\
\text { digital storytelling }\end{array}$ & & $X$ & & & $X$ \\
\hline M8 & & digital storytelling & & $X$ & & & $\mathrm{X}$ \\
\hline M9 & $X$ & & & $X$ & & & $\mathrm{X}$ \\
\hline M10 & & $\begin{array}{l}\text { videorecordings of } \\
\text { class activities }\end{array}$ & $\mathrm{X}$ & & & & $\mathrm{X}$ \\
\hline M11 & $X$ & & & & $\mathrm{X}$ & & $\mathrm{X}$ \\
\hline M12 & & $\begin{array}{l}\text { videorecordings of } \\
\text { class activities }\end{array}$ & & & $\mathrm{X}$ & & $\mathrm{X}$ \\
\hline $\begin{array}{l}\text { Frequency } \\
\text { count }\end{array}$ & 4 & 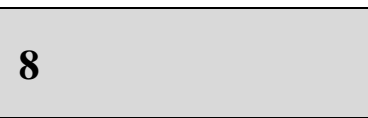 & $\begin{array}{ll}3 & 3\end{array}$ & 4 & 2 & 1 & 11 \\
\hline
\end{tabular}

The analysis of the CLIL teaching materials (Table 3) showed that the majority of them support and encourage the promotion of literacy in the minority language through written production-based activities in Friulian: Table 3 clearly shows that materials for young Primary school pupils are focussed on word-level production (M2, M4 and M5); materials for more advanced Primary pupils target sentence-level production (M6, M7, M8 and M9); finally, those aimed at Lower-Secondary pupils promote text-level production (M11 and M12). Only three teaching materials - two of which are for very young learners (M1 and M3) - do not to provide any writing tasks.

As far as the teachers' digital literacy is concerned, in line with findings just commented on, Table 3 shows that ICTs were adopted in the majority of CLIL teaching materials ( 8 out of 12): a variety of multimodal activities are provided, such as simple web-searches through the Interactive White Board and multimedia PowerPoint presentations, through to videorecordings of class activities and Digital Storytelling.

As for the promotion of the pupils' meta-competence and self-assessment, except for one CLIL teaching material - aimed at Kindergarten-level pupils (M1) - all the others envisage self-assessment activities for the pupils, aimed at improving their meta-competence and awareness of the minority language.

RQ2. How did participants perceive the exercise of key social skills aimed at creating a community of practice for the minority language teachers?

To answer this question, data from the teachers' feedback questionnaires, the teachers' diaries and the researchers' field notes were used. 


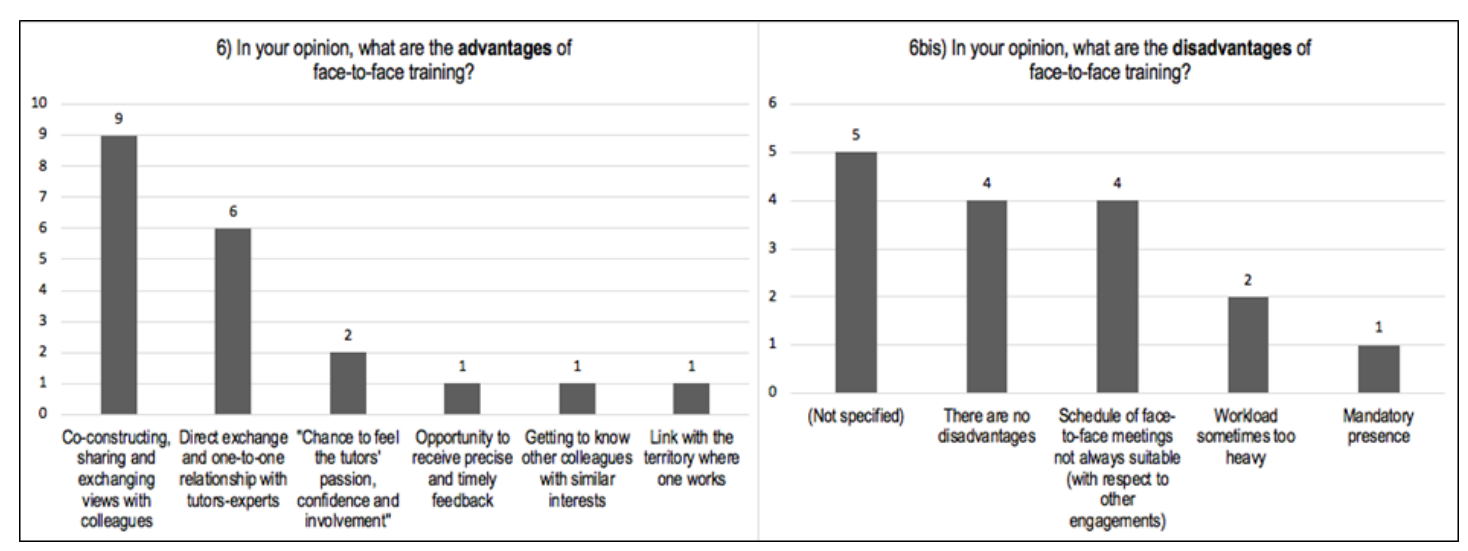

Figure 2. Answers from feedback questionnaires (item 6)

As can be seen in Figure 2, the possibility of sharing experiences, co-constructing and exchanging views with both fellow participants and teacher trainers (open-ended questionnaire item 6) seemed to be particularly appreciated. Not many disadvantages were highlighted, the only exception being the need to comply with a fixed schedule.

In contrast, Figure 3 shows that with regard to participants' perceived advantages and disadvantages of online training (open-ended questionnaire item 7) not many advantages were highlighted, except for the higher flexibility that online training can offer, while the most frequently cited disadvantages have to do with the lack of direct contact between participants which, according to some respondents, would lead to reduced learning.

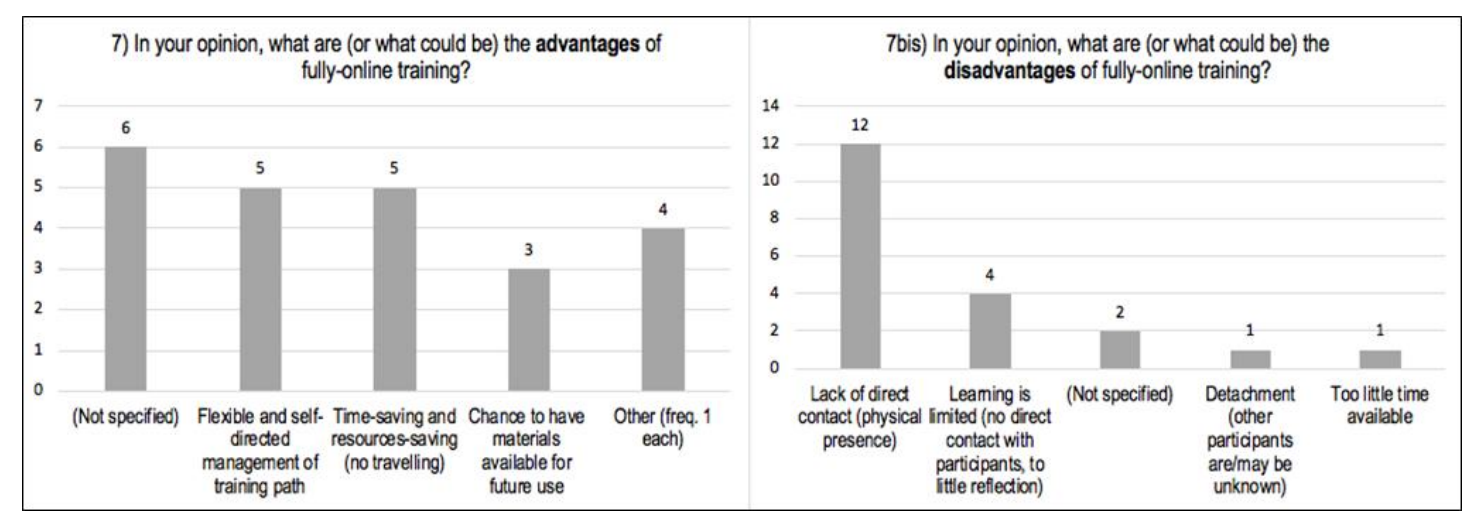

Figure 3. Answers from feedback questionnaires (item 7)

The analysis of the reflective questions in the teachers' diaries shows that the majority of teachers seemed to have appreciated the training programme offered, especially as far as the relationship with tutors is concerned, the possibility of working and sharing experiences both face-to-face and online, and the opportunity to receive continuous feedback on their output, i.e. teaching materials (quote 1). Nonetheless, in one case it appears that the training programme did not live up to prior expectations (quote 2).

[quote 1] It's been an interesting training opportunity, from the human point of view as well, thanks to the relationship with the tutors and their availability. The possibility to work from home and share ideas through the online platform has allowed greater freedom in time 
management to produce the teaching materials and then revise them after receiving feedback from the tutors, who monitored our work remotely. (Note 6)

[quote 2] [A course should] build work groups that are effective, where you plan, research, and share. You cannot actually define as a "work group" a group of people who work separately and relates to one tutor only (either in presence or online).

In addition, researchers' field notes were also consulted. As far as participation is concerned, whereas not all participants were always present in the face-to-face meetings in loco (due to other professional commitments), all of them took active part in all online sessions, i.e. in forum discussions on Moodle. Moreover, the possibility to constantly interact online, both with their colleagues and the tutors, allowed participants to receive timely feedback on their progress in the development of CLIL teaching materials, so that they could make the necessary changes and thus improve the quality of their work. With reference to the promotion of literacies in the minority language, some important issues were raised both during the face-to-face meetings and during the online sessions: the importance of developing functional literacy skills in order to make learning more meaningful (quote 3), the resistance on the part of some pupils and some parents, especially in areas of the Region where Friulian is not prevalent (quote 4), the issue of how to deal with the written language and oral varieties (Note 7) (quote 5), the scarcity of modern and attractive materials (quote 6), and, finally, their perceived insecurity in teaching literacy skills in Friulian (quote 7).

[quote 3] [L]ess-used terms, unless fixed in written form, tend to disappear or to be substituted with borrowings from Italian/English. To be so, a language needs to be listened to, spoken, written and, as a consequence, understood and produced.

[quote 4] We find it difficult to teach pupils how to write [in Friulian] (which for many people here should be considered as a foreign language), probably because it is scarcely used outside the school context.

[quote 5] Personally, I don't find any difficulty in reading with children as all varieties are allowed. As far as writing is concerned, I explained [to them] that there is a code which is the same for everybody and that little by little we will learn it. Children like it.

[quote 6] As far as learning to read and write in Friulian resources of all kinds are lacking (magazines, newspapers, books, television programmes,...); more specifically, instruments exist but are not valued, or they are perceived as if they were in a foreign language. Moreover, such materials rarely suit the needs of today's users: they lack appealing images, they lack modernity and do not take advantage of multimodality.

[quote 7] Additional difficulties concern the teachers themselves, their approach and confidence in the use of the written language.

RQ3. To what extent were learning-how-to-learn skills and teacher autonomy oriented to CLIL with a minority language fostered through the pilot programme?

With a view to answering this question, feedback from the questionnaires, the teachers' diaries and the researchers' field notes were contemplated. 


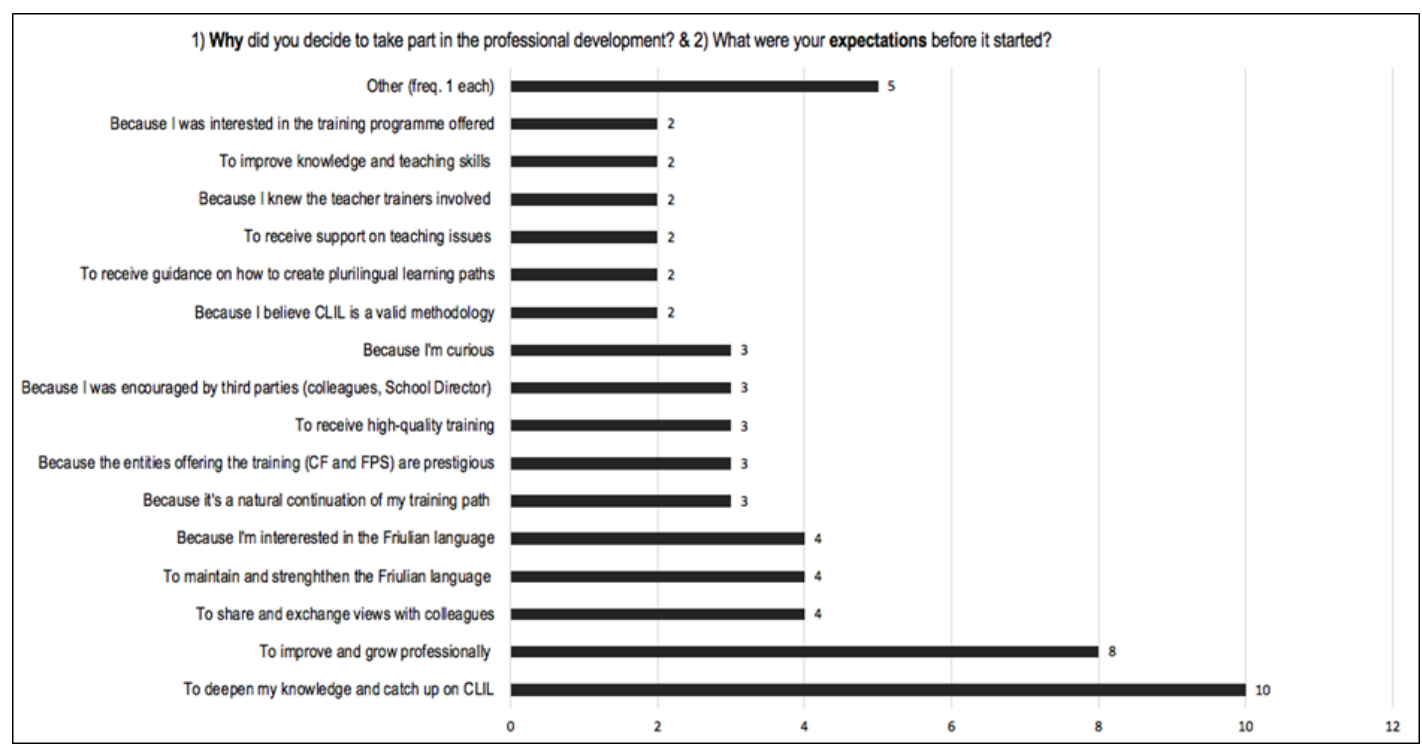

Figure 4. Answers from feedback questionnaires (items 1 and 2)

Among the reasons and expectations expressed by participants for taking part in the pilot training programme (open-ended questionnaire items 1 and 2), what stands out is the desire to improve knowledge of the CLIL methodology (10 respondents) and to grow professionally (8 respondents) (Figure 4).

As for participants' perceived success of the course in meeting their expectations (item 3, dichotomic yes/no: Was the professional development successful in meeting your expectations?), the great majority (16 out of 17) of the participants answered affirmatively, thus expressing full satisfaction with the training received.

When inquiring about whether such training had had an impact on their teaching (item 4, dichotomic yes/no: Do you think the professional development has had an impact on your teaching?), all teachers responded yes, confirming that the course positively influenced their way of teaching.

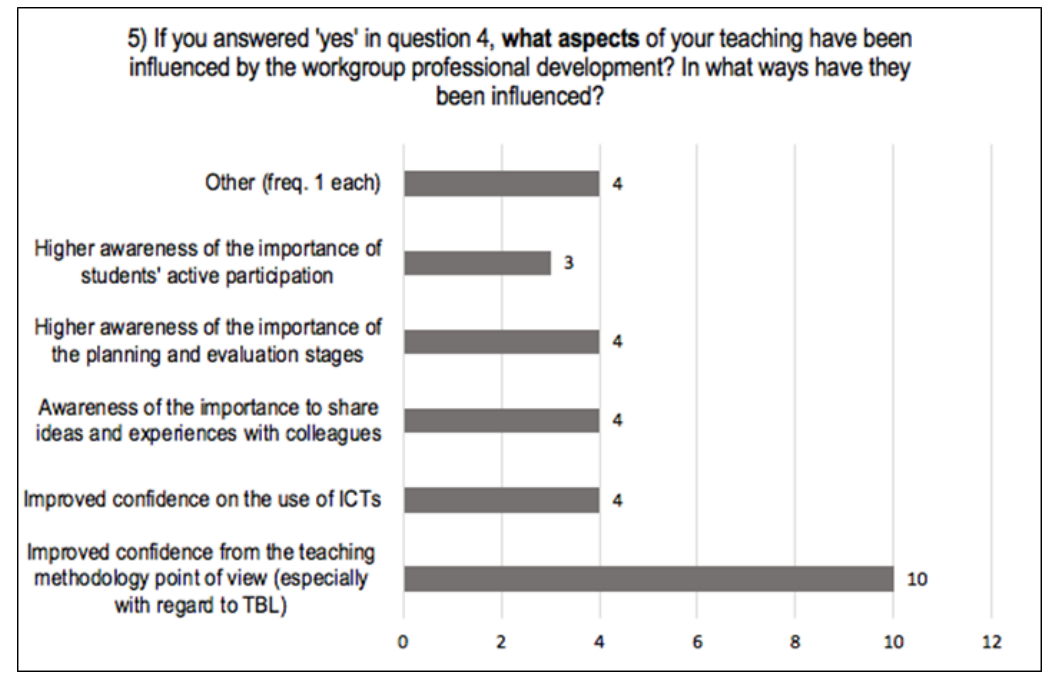

Figure 5. Answers from feedback questionnaires (item 5) 
More specifically, participants' answers to open-ended item 5 (Figure 5) reveal that the training produced positive effects both on their confidence - primarily from the teaching-methodology point of view, especially with regard to task-based learning (10 respondents) but also to the use of ICTs in teaching (4 respondents) - and on their awareness of the importance and usefulness of sharing ideas and experiences with colleagues (4 respondents), of careful planning (4 respondents), of active student engagement in class (4 respondents).

Consistent with the results presented above, the analysis of teachers' diaries revealed an orientation towards reflective teaching. In line with recommendations, for the majority (8 out of 12) of the CLIL modules the diary was compiled on a lesson-by-lesson basis, thus ensuring a high degree of systematicity in monitoring and reflection, whereas for only 4 of the modules the compilation took place at the end (cf. Table 2). Furthermore, answers to reflective questions reveal teachers' ability to identify their future training needs as far as CLIL in Friulian is concerned; recurrent themes mentioned by teachers regard integration strategies between content and language objectives, competence in the target language with a special focus on micro-language, and continuous support from experts. Furthermore, in their reflections, teachers raised issues such as the need to adopt a reflective teaching approach (see quotes 8, 9 below), also benefiting from cooperation with a colleague (quote 10), and the emotional rewards (quotes 11 and 12) attached to CLIL experiences in the minority language.

[quote 8] Adopt a constant research attitude: that is, being aware that what has been done could be revisited and re-thought (continuous research).

[quote 9] All teachers should experience CLIL as they could observe pupils' different attitudes towards learning.

[quote 10] It would be useful to engage in a CLIL training programme like this enjoying the possibility of co-teaching: the help from another teacher would allow to monitor groups more closely and optimise time management. [...] I haven't been able to record pupils' voices during lessons, take photographs and/or record a video as a means for documenting the work done.

[quote 11] The results obtained have been a source of great gratification for the teachers.

[quote 12] Reading pupils' reflections on their self-evaluation sheets (How did I work?) has been exciting: all of them made reference to the pleasure they felt for the activities carried out in Friulian during this module, showing a good degree of awareness of what they had learnt.

In the researchers' field notes, with reference to the use of Friulian during the training programme, it was noticed that the first attempts to encourage participants to interact in the online forum using the target language (Friulian) encountered resistance on the part of some of them, which led to sporadic and non-systematic use of the language during (written) interaction online. 


\section{Discussion}

The data collected during the piloting of our teacher training programme has allowed us to understand whether the model of teacher development in CLIL for minority language teachers underpinning such programme was effective with respect to the three components of the model itself, i.e. teaching skills, social skills, and learning-how-to-learn skills. Despite the small number of participants enrolled in the pilot programme, the analysis of data has highlighted some important issues that are worth discussing.

As for the first component, namely the teaching skills promoted, it was found that the programme was overall successful: the great majority of teachers showed they had gained a high level of understanding of the CLIL approach and of related teaching aspects, such as the importance of careful lesson planning and wise use of scaffolding techniques to facilitate input comprehension and develop multiple literacy skills in Friulian. All this was detected in the CLIL teaching materials they produced during the course; for example, the high frequency of learning activities for developing writing skills indicates that the training programme had managed to make teachers realise the central role of literacy skills for the promotion of academic proficiency in the minority language. Apart from the materials produced at kindergarten level - for obvious reasons - in all the others, the higher the school level they targeted, the higher the demand for written production by the pupils (at word, sentence and text level). Written language-based activities took into consideration not only the constructs underlying literacy development (phonological structures, alphabetic principle, decoding and encoding, oral and written comprehension and production, Foorman et al., 2011) but also the broader learning context. While for some teachers, teaching in areas where the language is widely present and regularly spoken by their pupils, the promotion of literacy skills in the minority language was perceived, to some extent, as a natural continuation of the formal study of the language, for other teachers the need to devote greater attention to reading and writing in Friulian was not as straightforward. In fact, in those areas of the Region where the language is less spoken, like in urban areas in the Southern part of the province of Pordenone, resistance towards the language often comes from both families and pupils alike (cf. quote 4), a circumstance that hinders the potential for literacy development in Friulian through schooling. Another literacy-related issue that was raised during the training programme had to do with the coexistence of local varieties of Friulian (cf. Benincà \& Vanelli, 2016) with the standard language, and their role in formal learning. Although varieties are allowed in their oral forms, in writing there is the need to adopt the official spelling, as established by the Regional Law 15/1996, a problem that teachers had to face while developing materials targeting the pupils' literacy skills (cf. quote 5). In particular, some teachers admitted not feeling so confident in dealing with local varieties in curricular teaching; therefore, we believe that the issue of the promotion of local varieties alongside the standard variety (for writing) deserves greater attention at the level of language policy in education.

Together with the promotion of more traditional literacy skills, teachers understood the importance of designing modern, attractive, multimodal, and multiple literacy-oriented materials by embedding ICT-based learning activities into their teaching materials (cf. quote 
6): CLIL materials in Friulian need to be as appealing as those in the other (majority) languages to capture students' attention, increase their motivation and allow for multiple literacy skills development. Finally, attention to pupil self-assessment was present in all the CLIL materials produced, which shows thoughtful consideration of the need to make learning meaningful and visible to students, and therefore to create occasions for them to reflect on their achievements, difficulties and beliefs throughout the learning process.

The analysis of the second component of the model, which had to do with the development of those social skills beneficial for a community of practice where teachers (and trainers) collaborate and co-construct their knowledge, has highlighted some inconsistencies between the teachers' perceptions of the importance of social learning and their beliefs about blended learning. On the one hand, participants appreciated being part of a community of peers with whom to exchange ideas and experiences in the teaching of a minority language, both in face-to-face meetings and in an online environment (cf. quote 1). According to some scholars, "the greatest potential for online communities of practice is to function as a supplement to already existing local offline communities" (cf. Matzat, 2013, p. 42). Most of the Friulian teachers who took part in this training programme can be classified as "a local offline community", in the sense that almost all of them already knew each other before due to previous training in CLIL or to working together in school projects in Friulian. However, it seems that this pre-existing local community of teachers is not yet ready to turn into an online community. In fact, the majority of participating teachers are still convinced that face-to-face meetings remain the best modality to be trained through. Apparently, they do not taking into account that physical presence is not a necessary condition for productive exchanges of views and meaningful learning experiences, which can happen online as well, by means of forum discussions for example (which, in turn, encourage participants to write in the target language and reflect on their competence). Furthermore, if regular class attendance is associated with better performance (cf. Clark \& Post, 2019) and is, therefore, an important factor to consider when assessing the efficacy of a programme, it is significant to stress that in our training course the attendance rate was higher in online sessions than in face-to-face meeting. All this shows that teachers do not appear to be fully aware of the training potential offered by blended environments (or, perhaps, they are not - as yet - entirely 'comfortable' in such environments).

Finally, findings related to the third component of the teacher development model, aimed at promoting teacher autonomy, were rather encouraging. Barfield et al. (2001 cited in Kojima, 2019, p. 73) identified the following aspects involved in teacher autonomy: 1) negotiation skills, 2) readiness to engage in lifelong learning, 3) reflection on the teaching process and environment, and 4) commitment to promoting learner autonomy. Our findings revealed that, by the end of the programme, participant teachers had increased their skills and awareness in all these aspects. Their negotiation skills were trained through team-work and collaborative activities; furthermore, the fact that many of them highlighted the wish for co-teaching indicates a good understanding of the benefits deriving from co-planning and co-instructing, as well as from exchanging views, learning new strategies, receiving feedback from a colleague or getting help in monitoring what happens in class (cf. quote 10). As far as 
readiness to engage in lifelong learning is concerned, the fact that teachers decided to enrol voluntarily in this pilot training programme focussing on literacy skills in Friulian, not only reveals their strong interest in the contents of the course itself, but also their willingness to develop their professional skills. Their orientation to lifelong learning is also evident in their identification of specific future training needs specifically related to the development of the literacies in the minority language in their pupils (such as a greater focus on micro-language, for example), as reported in the teachers' diaries at the end of the pilot programme.

The specific actions aimed at fostering teacher autonomy in terms of learning-how-to-learn skills also led to reflection on the teaching process and environment. This pilot programme helped teachers reflect on their practice in different ways: by adopting a teacher diary - to annotate details related to their teaching in CLIL together with reflections on the results of such lessons, in terms of learning achievement, learner motivation, aspects needing improvement, etc.; by participating in online discussion forum - on themes such as, for example, their role in promoting the minority language in a more effective way, or the institutional barriers they had to face in order to introduce a new approach into the school system; by being involved in a formative and peer assessment process throughout the whole training programme - so as to be able to monitor and evaluate the effectiveness of their own and their colleagues' literacy development oriented-teaching, while being ready to make changes or suggest solutions. Reflection also led to the recognition of the emotional rewards connected to the new teaching experience, as is evident in participants' quotes (cf. quotes 11, 12). Finally, with reference to the last of the teacher-autonomy related aspects listed in Kojima (2019, p. 73), namely, commitment to promote learner autonomy, it can be argued that the pilot training programme led to positive outcomes here as well. By including self-assessment activities into their CLIL teaching materials (as discussed above), the trained teachers demonstrated their awareness of the importance of the pupils' role as an active participant in the learning process - evident also in their reflections (cf. quote 12).

Besides the encouraging findings as reported above, a rather important limit in the application of the teacher training model needs to be acknowledged with reference to the use of the target language (i.e. Friulian) during the training programme. Given that the first attempts to encourage participants to interact in the forum using Friulian encountered resistance on the part of some of them, the use of the target language during (written) interaction online was sporadic and non-systematic. Some teachers did not feel at ease when writing in Friulian and felt insecure in the task of developing literacy skills in their pupils (cf. quote 7). Furthermore, unfortunately, almost all the teacher-trainers were not competent in the minority language, so most of the training programme was run in Italian, thus limiting the opportunities for teachers to develop their own meta-competence in Friulian. Notwithstanding this, such concerns seemed to diminish by the end of the course, presumably because of increased levels of teacher awareness and sense of empowerment.

However, that said, if this programme were to be repeated, we would suggest that trainers be competent in the minority language itself so that the linguistic meta-competence dimension of the training might be addressed more appropriately. 


\section{Macrothink}

\section{Conclusions}

Albeit insufficient in itself (cf. Ó Duibhir, 2019), education plays a necessary role as it can equip students with the right tools to develop literacies in the minority language, thus promoting the language itself - not just maintaining it - as a useful tool in all domains of life. More specifically, what is needed is that multiple literacy skills become a curricular learning milestone and that teachers know how to reach it.

In line with this, a new model of teacher development in CLIL for minority language teachers has been devised and piloted, its main components regarding teachers' teaching skills, social skills and learning-how-to-learn skills. Despite low generalisability due to the small number of subjects involved, our findings revealed that, by the end of the pilot programme, participating teachers had increased their awareness of and competence in all those skills. Although the study presented limitations, such as a rather limited use of the target language as working language throughout the programme, we believe that the model we piloted has the potential to bring multiple literacy skills in the minority language at the centre of curriculum development.

\section{Acknowledgements}

The Authors wish to express gratitude to the teachers who participated in the training programme, and to the Societât Filologjiche Furlane, whose contribution was invaluable.

\section{References}

ARLeF-Agjenzie Regjonâl pe Lenghe Furlane. (2015). Ricerca sociolinguistica sulla lingua friulana. Regione Autonoma Friuli Venezia Giulia. Retrieved from https://arlef.it/app/uploads/materiali/1-ricerca-sociolinguistica-sulla-lingua-friulana-2015.pdf

Baker, C. (2007). Becoming bilingual through bilingual education. In P. Auer, \& L. Wei (Eds.), Handbook of multilingualism and multilingual communication (pp.131-152). Berlin: Mouton de Gruyter. https://doi.org/10.1515/9783110198553.1.131

Baker, C. (2011). Foundations of bilingual education and bilingualism (Vol. 79). Clevedon: Multilingual Matters.

Benincà, P., \& Vanelli, L. (2016). Friulian. In A. Ledgeway, \& M. Maiden (Eds.), The Oxford guide to the Romance languages (pp. 139-153). Oxford: Oxford University Press. https://doi.org/10.1093/acprof:oso/9780199677108.003.0010

Bialystok, E. (2001). Bilingualism in development: Language, literacy, and cognition. Cambridge: Cambridge University Press. https://doi.org/10.1017/CBO9780511605963

Charmaz, K. (2006). Constructing Grounded Theory: A Practical Guide Through Qualitative Analysis. SAGE.

Cisilino, W. (2014). Laws for the protection of the Friulian Language. In R. Mucignat (Ed.), The Friulian language: Identity, migration, culture (pp. 15-27). Cambridge: Cambridge Scholars Publishing. 


\section{Macrothink}

International Journal of Linguistics

ISSN 1948-5425

2020, Vol. 12, No. 3

Clark, C., \& Post, G. (2019). The value of student attendance at face-to-face classes, as part of a blended learning experience. ASCELITE: 36th International Conference on Innovation, Practice and Research in the Use of Educational Technologies in Tertiary Education, Singapore University of Social Sciences. Retrieved from https://2019conference.ascilite.org

Coonan, C. M. (2011). CLIL in (language) teacher training. Studi di Glottodidattica, 2, 1-14. https://doi.org/10.3299/sdg.v5i2.1-14

Cope, B., \& Kalantzis, M. (Eds.). (2015). A pedagogy of multiliteracies: Learning by Design. Basingstoke: Palgrave Macmillan. https://doi.org/10.1057/9781137539724

De Santo, M., \& De Meo, A. (2016). E-training for the CLIL teacher: e-tutoring and cooperation in a Moodle-based community of learning. Journal of E-Learning and Knowledge Society, 12(3), 41-49. https://doi.org/10.20368/1971-8829/1152

Di Martino, E., \& Di Sabato, B. (2012). CLIL implementation in Italian schools: Can long-serving teachers be retrained effectively? The Italian protagonists' voice. Latin American Journal of Content and Language Integrated Learning, 5(2), 73-105. https://doi.org/10.5294/laclil.2012.5.2.9

Dörnyei, Z. (2007). Research Methods in Applied Linguistics: Quantitative, Qualitative and Mixed Methodologies. Oxford, UK: Oxford University Press.

Eisenchlas, S. A., Schalley, A. C., \& Guillemin, D. (2013). The importance of literacy in the home language: The view from Australia. Sage Open, 3(4). https://doi.org/10.1177/2158244013507270

Foorman, B. R., Arndt, E. J., \& Crawford, E. C. (2011). Important constructs in literacy learning across disciplines. Topics in Language Disorders, 31, 73-83. https://doi.org/10.1097/TLD.0b013e31820a0b86

Hopkins, D. (1985). A teacher's guide to classroom research. Milton Keynes: Open University Press.

Johnson, D. W., \& Johnson, R. (1989). Cooperation and competition: theory and research. Edina, MN: Interaction Book Company.

Kojima, H. (2019). Developing autonomy in EFL learning and teaching: A portfolio program under collaborative and reflective supervision. In M. Menegale (Ed.), Autonomy in language learning: getting learners actively involved (pp. 71-87). Hong King: Candlin \& Mynard.

Lave, J., \& Wenger, E. (1991). Situated learning, legitimate peripheral participation. Cambridge: Cambridge University Press. https://doi.org/10.1017/CBO9780511815355

Malone, S. (2004). Education for Multilingualism and Multi-literacy in Ethnic Minority Communities. $A B D, 34(2), 6-9$.

Matzat, U. (2013). Do blended virtual learning communities enhance teachers' professional development more than purely virtual ones? A large scale empirical comparison. Computers \& Education, 60, 40-51. https://doi.org/10.1016/j.compedu.2012.08.006 
Mezgec, M. (2011). Literacy skills in minority language: the case of the Slovene minority in Italy. Annales-Anali za Istrske in Mediteranske Studije-Series Historia et Sociologia, 21(1), 71-78. Retrieved from http://www.dlib.si/details/URN:NBN:SI:DOC-OQ1QFA5D

Moseley, C. (Ed.). (2010). Atlas of the World's Languages in Danger (3rd ed.). Paris: UNESCO. Retrieved from http://www.unesco.org/culture/en/endangeredlanguages/atlas

Ó Duibhir, P. (2019). Bilingual Education in Minority Language Contexts: When a High Level of Linguistic Competence is Not Enough. ELIA Estudios de Lingüistica Inglesa Aplicada, 1, 39-64. https://doi.org/10.12795/elia.mon.2019.i1.03

Papaja, K. (2013). The role of a teacher in a CLIL classroom. Glottodidactica, 40(1), 147-153. https://doi.org/10.14746/gl.2013.40.1.11

Perini, R. (2006). Il friulano nella Regione Friuli Venezia Giulia. In F. R. Garotti (Ed.), Ilfuturo si chiama CLIL, Una ricerca interregionale sull'insegnamento veicolare (pp. 227-234). Trento: Provincia Autonoma di Trento, IPRASE.

Perini, R. (2010). Clin d'oeil sur la langue: Marilenghe. L'écôle Valdotaine, 84, 53-55.

Perini, R., \& Senesi, T. (Eds.). (2012). Local Lingue Infanzia. Roma: Anicia.

Petris, C. (2014). Regional Dossier: The Friulian language in education in Italy. Mercator European Research Centre on Multilingualism and Language Learning. Fryske Akademy.

Richards, J. C., \& Lockhart, C. (1996). Reflective Teaching in Second Language Classrooms. Cambridge: Cambridge University Press.

Valtin, R., Bird, V., Brooks, G., Brozo, B., Clement, C., Ehmig, S., \& Tamburlini, G. (2016). European declaration of the right to literacy. Cologne: European Literacy Policy Network (ELINET). Retrieved from http://www.eli-net.eu/fileadmin/ELINET/Redaktion/user_upload/European_Declaration_of_t he_Right_to_Literacy2.pdf

Van Dongera, R., Van der Meer, C., \& Sterk, R. (2017). Research for CULT Committee-Minority languages and education: best practices and pitfalls. European Parliament: Policy Department for Structural and Cohesion Policies.

Vygotsky, L. S. (1962). Thought and language (trans. E. Hanfmann, \& G. Vakar). Cambridge: Massachusetts Institute of Technology. https://doi.org/10.1037/11193-000

\section{Notes}

Note 1. Council of Europe (1992). European Charter for Regional or Minority Languages, ECRML. European Parliament (2009). Resolution of 24 March 2009 on "Multilingualism: an asset for Europe and a shared commitment" (2008/2225(INI)).

Note 2. Norme in materia di tutela delle minoranze linguistiche storiche. Roma: Gazzetta Ufficiale della Repubblica Italiana, n. 297. 


\section{Macrothink}

International Journal of Linguistics

ISSN 1948-5425 2020, Vol. 12, No. 3

Note 3. Norme per la tutela, valorizzazione e promozione della lingua friulana. Trieste: Bollettino Ufficiale Regionale, n. 52.

Note 4. http://www.eli-net.eu/about-us/

Note 5. Teachers' diaries can be found in appendix to each CLIL module (http://www.eduka2.eu/materiali-didattici/insegnamento-friulano/).

Note 6. All the teachers' quotes have been translated into English by the Authors.

Note 7. Like many other minority languages, Friulian as well has local varieties which differ in terms of various phonological, morphological and syntactic aspects (cf. Benincà \& Vanelli, 2016). While local varieties are allowed in their oral, spoken forms, written language needs to comply with the official writing system as established by the Regional Law 15/1996.

\section{Copyrights}

Copyright for this article is retained by the author(s), with first publication rights granted to the journal.

This is an open-access article distributed under the terms and conditions of the Creative Commons Attribution license (http://creativecommons.org/licenses/by/4.0/) 